\title{
МОВНОСТИЛІСТИЧНІ ОСОБЛИВОСТІ ДИСКУРСУ У СФЕРІ ДИПЛОМАТІЇ (НА МАТЕРІАЛІ ПРОМОВ ПОЛІТИКА ПЕТРА ПОРОШЕНКА ТА ПРЕЗИДЕНТА УКРАЇНИ ВОЛОДИМИРА ЗЕЛЕНСЬКОГО)
}

\begin{abstract}
Анотація. Роботу «Мовностилістичні особливості дискурсу у сфері дипломатії (на матеріалі промов політика Петра Порошенка та Президента України Володимира Зеленського)» присвячено дослідженню мовностилістичних особливостей промов політиків. Політика, дипломатія та міжнародні відносини стали невід'ємною частиною нашого життя і впливають на перебіг подій у різних точках планети. Потрібно розуміти, що правильне розуміння та коректне трактування тих чи інших політичних висловлювань напряму впливають на результат взаємодії держав між собою, а отже не можуть залишитись без уваги дослідників. Аналіз політичного дискурсу дозволяе визначити основні мовностилістичні прийоми політиків такі як: маніпуляції, гіперболізації, негативно забарвлені епітети, фразеологізми, а також риторичні запитання. Визначивши і проаналізувавши ці прийоми ми зможемо дійти до розуміння мети їхьього використання, нівелювати вплив та зробити правильні висновки. Дане дослідження було б неможливим без провідних праць О.Й. Шейгал, Н.В. Шевчука, Н.В. Кондратенка, О.К. Ковальової, Г.Я. Солганіка, Л.І. Мацько та ін. у сфері політичного дискурсу. Значення роботи відображаеться у виявленні та аналізі мовностилістичних особливостей, а саме метафор, негативно забарвлених, гіперболізованих епітетів, метонімії, маніпуляцій у промовах та листах політиків, на політичній арені ООН.
\end{abstract}

Ключові слова: дискурс-аналіз, промова, маніпулювання, політичний дискурс, міжнародні відносини.

Romanyshyn Nataliia, Huzan Artem Lviv Polytechnic National University

\section{LINGUISTIC FEATURES OF DISCOURSE IN THE FIELD OF DIPLOMACY (BASED ON SPEECHES BY THE PRESIDENT OF THE UN ASSEMBLY VOLKAN BOZKIR AND THE PRESIDENT OF UKRAINE VOLODYMYR ZELENSKY)}

Summary. The work "Linguistic features of discourse in the field of diplomacy (based on the speeches of the politician Petro Poroshenko and President of Ukraine Volodymyr Zelensky)" is devoted to the study of linguistic and stylistic features of politicians' speeches. Politics, diplomacy and international relations have become an integral part of our lives and influence the course of events in different parts of the world. It should be understood that the correct understanding and correct interpretation of certain political statements directly affect the outcome of interaction between states, and therefore cannot be ignored by researchers. Analysis of political discourse allows us to identify the main linguistic and stylistic devices of politicians such as: manipulation, hyperbole, negatively colored epithets, phraseology, and rhetorical questions. Having identified and analyzed these techniques, we will be able to understand the purpose of their use, level the impact and draw the right conclusions. This study would have been impossible without the leading works of O.Y. Sheigal, N.V. Shevchuk, N.V. Kondratenko, O.K. Kovaleva, G.Ya. Solganik, L.I. Matsko, and others. in the field of political discourse. We used analysis and synthesis to form the theoretical basis of our study. In order to identify all language units, as well as their features and functions, we used a descriptive research method. Comparative analysis helped to find similar and different properties of the studied elements. In order to obtain and analyze the frequency of used linguistic and stylistic elements, we used a statistical method of research. The value of the work is reflected in the identification and analysis of linguistic and stylistic features, namely metaphors, negatively colored, exaggerated epithets, metonymy, manipulation of speeches and letters of politicians in the UN political arena. The relevance of the study of political speeches, resolutions and letters are extremely important in the context of Ukraine's integration into the world community for full awareness of the world situation, development of critical thinking and formation of their own, unbiased position, unbiased assessment of politicians and determination of the result. also defining methods of conflict resolution.

Keywords: discourse analysis, speech, manipulation, political discourse, international relations.

$\prod$ остановка проблеми. Роль міжнаОсобливе значення має їхнє лінгвістичне тлумачення, без чого неможлива комунікація на міжнародному рівні, досягнення правильних рішень та взаєморозуміння між країнами. Це, своєю чергою, зумовлюе вагомість нашого дослідження, присвяченого вивченню особливостей мови дипломатичного дискурсу.

Аналіз останніх досліджень і публікацій. Дослідження політичного дискурсу є надзвичайно актуальним і корисним адже коректна інтер- претація виступів вагомих політичних діячів прямо впливає на міжнародні відносини. Дане дослідження було б неможливим без праць таких авторів, як: Завальнюк І.Я., Кривенко С.-В.О., Лящук М.О., Нагорна Л.Б. та ін., які активно досліджують поняття політичного дискурсу і його вплив на міжнародні відносини.

Метою статті $є$ визначення та аналіз мовностилістичних особливостей англомовних текстів міжнародних відносин. Об'єктом дослідження $є$ англомовні промови, взяті з офіційних джерел $\mathrm{OOH}$, а саме дослідження було зроблене на ма- 
теріалі публічних виступів Петра Порошенка та Президента України Володимира Зеленського на з їздах Генеральної Асамблеї ООН.

Виклад основного матеріалу. Важливо розуміти, що сучасне розуміння терміну «дискурс» не є однозначним [7]. На думку вченої В. Є. Чернявської дискурс у найширшому понятті - це сукупність тематично співвіднесених текстів. Автор зауважуе, що поняттю «дискурс» у публікаціях останніх десятиліть приділяеться особлива увага [4]. Більш широко розкриває поняття дискурсу швейцарський дослідник П. Серіо: еквівалент поняття «мовлення», будь-яке конкретне висловлювання; одиниця, більша від фрази; вплив висловлення на адресата 3 урахуванням комунікативної ситуації; теоретичний конструкт, призначений для аналізу, продукування тексту [3]. Проаналізувавши різні тлумачення терміна «дискурс» у багатьох лінгвістів, ми можемо виявити подібні риси цього поняття. Дискурс - це логічно збудований текст, який існує у певному контексті. Він не може існувати окремо від сучасності, завжди несе в собі екстралінгвістичну проблематику і тісно пов'язаний із життям.

Дипломатична діяльність породжує тексти усні і письмові - що належать до політичного дискурсу. Як і було сказано вище, вивчаючи проблеми фонкціонування політичної мови, сучасні вчені зазвичай використовують для опису цього явища термін "політичний дискурс», який в останні десятиріччя набуває широкого змісту. Політичний дискурс - явище складне і багатопланове, тому досі не має чіткого визначення. Єдиного розуміння політичного дискурсу немає з огляду на кілька моментів. По-перше, немає єдиної науки, яка би мала об'єктом дослідження політичний дискурс. По-друге, саме поняття позначає результат складної взаємодії членів суспільства, що має різні прояви: культурний, політичний, лінгвістичний, символічний тощо. По-трете, дуже важко вивести певні закономірності функціонування політичного дискурсу, бо в ньому самому закладені семантичні парадокси [1].

Процес маніпулятивного впливу на суспільну свідомість є цілком можливим за допомогою залучення певних стилістичних та синтаксичних особливостей мовлення. Сама ж мова представляе таку систему знаків, яку ми маємо шанс використовувати задля позначення справді існуючих конкретних об'єктів; певні слова здатні служити для цілі утворення специфічних образів. Знаковий і символічний сенс мови дає нам змогу здійснювати маніпулятивні махінації над свідомістю багатьох людей у процесі політичного дискурсу [2].

У даній роботі під мовною маніпулящією, за визначенням В. Є. Чернявської, розуміеться «мовний вплив, спрямований на приховане спонукання адресата до вчинення певних дій», тобто фрормування у свідомості адресата установок, які співпадають з установками адресанта. При маніпулящії адресант намагається переконати особу прийняти певні висловлювання за справжні без опори на докази [5].

Дослідження політичного дискурсу неможливе без вивчення й аналізу політичної мови та політичного тексту насамперед тому, що політичний дискурс, як зазначалось раніше, - це тематична мережа політичних текстів, що передбачають тему, яка визначає взаемозв'язок між дискурсом та практичною, соціологічною, психологічною, культурною, мовною та іншими сорерами. Отже, політичний текст - це інструмент досягнення влади. Між мовою та політикою завжди існував тісний зв'язок. У політичній комунікації мова має велике значення, тому що $є$ найпотужнішою зброєю в політичній боротьбі. Тобто йдеться про спілкування між представниками соціальних інститутів, що відбувається в конкретних соціальних умовах. У нашій роботі дотримуємося вузького підходу до відбору текстів, обравши для дослідження лише інституційні, офріційні тексти президента Асамблеї ООН.

Повернемось детальніше до політичної промови Петра Порошенка. У політичній промові П. Порошенка тропи посідають не останне місце і політик використовуе їх майже у кожному логічному абзаці. Поміж згаданих прикладів ми можемо виділити основний епітет, який переходить з одніеї фррази в іншу - very: the very beginning Ukraine, very concrete steps, very bad about Ukraine, very important, repeat very clearly, be very clear, the very survival, currently very difficult, the very thing our charter. Також це можна поєднати 3 надмірною гіперболізацією у промовах, яка теж неодноразово зустрічалась в промовах П. Порошенка:

"This is all highly reminiscent of the Soviet repressive machine now applied to break the courage of a Ukrainian woman».

"Remembering the most dramatic days of Maidan, I hope that the most difficult time of Donbas bloodshed is over».

3-поміж стилістичних фрігур автор вживає парцеляцію як засіб експресивізації. У мовознавстві здебільшого парцельовані структури називають «приеднувальними конструкціями», хоча їх не можна ототожнювати в силу того, що приєднування - це суто мовленневе доповнення змісту речення, а парцеляція - це мовленневе членування єдиного системного цілого:

"The confidence that territorial claims, aggression, a right of might belonged to the past, at least in Europe. But now, this confidence has been shattered».

«Thousands of people have been killed since last April. More than ten thousands wounded. Hundreds and thousands of civilians have become innocent victims of terrorists financed, trained and equipped by Russia».

Цікавою стилістично є промова В. Зеленського на загальних дебатах 75-ї сесії Генеральної Асамблеї ООН. Промова розпочинається з багатокомпонентного поширеного звертання, що визначає ставлення мовця до адресата. Використані звертання виражають повагу, вдячність, стають емоційними центрами речення, створюють відтінки урочистості, ліричності: «Distinguished Mr. President!».

Мовлення є дуже образним, насиченим метафороми:

- Mankind has conquered space and can even hold UN meetings remotely, using modern technology / At the same time, we must recognize that the system is increasingly failing. It is attacked by new "bugs" and "viruses" / We managed 
to unblock the dialogue, we resumed meetings of the leaders of the Normandy format countries, we made significant progress in the mutual release of detainees / And on July 27, a comprehensive ceasefire began, which, despite attempts to disrupt it, still gives hope for a stable "silence" / On the contrary, as long as the wound in central Europe is bleeding, the whole world will feel the pain. And the only recipe for effective treatment is the deoccupation of Crimea and Donbas.

Метафоризація дозволяе політичному лідерові створити яскраві образи, дати оцінку подіям, висловити емоціональне ставлення до предмета мови, вона має великий вплив на адресата мови.

Метафоризуючись, діеслова та словосполучення посилюють свої динамічні властивості й використовуються як художньо-образний засіб: humanity was able to recover / united to build a better world together / the wound in central Europe is bleeding / the whole world will feel the pain / recipe for effective treatment is the deoccupation / a new information bomb explodes on the global agenda / Coronavirus spares noone. Серед дієслівних форм переважають особові. Поєднання різночасових форм підкреслює взаємозалежність, зв'язок минулого й сучасного, теперішнього й майбутнього, що створюе необхідні передумови емоційного впливу на читача (wish to achieve / I am convinced / happened to steer / we discussed / we would say / united to build / have been made / has conquered / we must recognize).
У промові й відповідно в суспільній свідомості здійснюється актуалізація таких ключових слів, як незалежна Україна, спільна справа, єдність, війна, анексія, спільний ворог, боротьба, насилля. Ці ключові слова створюють змістову домінанту промови.

Також промова Зеленського наповнена порівняннями та іншомовними запозиченнями:

- But could anyone at least imagine that 2020 would stage such a crash test for the planet? / A year ago, we would say that this is a script of an apocalyptic blockbuster, not the realities of 2020 / World War II was a planetary "earthquake" that claimed tens of millions of lives.

Ми не зустріли жодного прямого вживання слів «пандемія», «ковід», вони були замінені «краш-тест», «блок-бастер», «реалії 2020»; Speaking the language of the same technology, the UN has become "software" that saved the world from critical error / At the same time, we must recognize that the system is increasingly failing. It is attacked by new "bugs" and "viruses".

Висновки. Отже, ми детально охарактеризували таке явище, як дискурс, проведено всебічний аналіз всіх його областей і аспектів, а саме основні його поняття і терміни, семітичний аспект, природа явища політичного дискурсу. Також було проаналізовано лексико-синтаксичні особливості політичного дискурсу на прикладі промов відомого політичного діяча Петра Порошенка та Президента України Володимира Зеленського.

\section{Список літератури:}

1. Кривенко С.-В.О. Семантична парадоксальність політичного дискурсу (теоретико-методологічний аналіз) : авторедр. дис. ... канд. політ. наук : 23.00.01. Львів. нац. ун-т ім. І. Франка. Львів, 2016. 19 с. укр.

2. Лящук М.О. Лексико-семантичні та лінгвостилістичні особливості політичного дискурсу на прикладі промов Дональда Трампа. Острог, 2020. 96 с.

3. Сусов И. П. История языкознания : учебное пособие для студентов старших курсов и аспирантов. Тверь, 1999. 327 c.

4. Чернявская В.Е. Дискурс власти и власть дискурса. Москва : Флинта : Наука, 2006. 136 с.

5. Orpin D. Corpus linguistics and critical discourse analysis. Examining the ideology of sleaze. International Journal of Corpus Linguistics. 2005. № 10(1). P. 37-61.

\section{References:}

1. Kryvenko S.-V.O. (2016) Semantychna paradoksalnist politych-noho dyskursu (teoretyko-metodolohichnyi analiz): avtoref. dys. ... kand. polit. nauk: 23.00.01. Lviv. nats. un-t im. I. Franka. Lviv, 19 p. ukr.

2. Liashchuk M.O. (2020) Leksyko-semantychni ta linhvostylistychni osoblyvosti politychnoho dyskursu na prykladi promov Donalda Trampa. Ostroh, $96 \mathrm{p}$.

3. Susov Y.P. (1999) Ystoryia yazykoznanyia: uchebnoe posobye dlia studentov starshykh kursov y aspyrantov. Tver, $327 \mathrm{p}$.

4. Chernyavskaya V.E. (2006) Diskurs vlasti i vlast' diskursa. Moscow: Flinta: Nauka, 136 p.

5. Orpin D. (2005) Corpus linguistics and critical discourse analysis. Examining the ideology of sleaze. International Journal of Corpus Linguistics, no. 10(1), pp. 37-61. 